\author{
Nama : Mia Grace Angel \\ Nirm : 2020196659 \\ Kelas : G (Teologi ) \\ miagraceangel147@gmail.com
}

\title{
Peran Orang Tua dalam Pembentukan Iman dan Karakter Anak
}

Abstrak : Dalam kajian tulisan ini, hendak menjabarkan peran orang tua dalam pembentukan iman dan karakter anak dengan memahami arti peranan orang tua bagi anak dalam pembentukan iman dan karakter.

Kata kunci : Iman, Karakter Anak, Peran orang tua

\section{Pendahuluan}

Pembentukan karakter dan pendidikan karakter menjadi suatu keharusan, karena pendidikan tidak hanya mengantarkan anak bangsa menjadi cerdas tetapi juga mempunyai budi pekerti dan sopan santun, sehingga keberadaannya sebagai anggota masyarakat menjadi bermakna baik bagi dirinya maupun bagi masyarakat pada umumnya. Artinya, dengan melekatnya indikator perilaku tersebut pada setiap anak bangsa dalam proses pendidikan, sebagaimana yang disebutkan dalam tujuan pendidikan nasional diatas, maka telah mencerminkan sosok individu yang berkarakter

Pendidikan iman dan karakter bukan hanya diperoleh melalui pendidikan formal di sekolah, tetapi lebih diperoleh dalam keluarga. Pendidikan Iman tidak ditentukan oleh pendidikan formal di sekolah tetapi lebih dominan di peroleh/ dipelajari justru melalui budaya. Iman lebih dipengaruhi melalui pembentukan kebudayaan (kultur).

Perilaku itu dibentuk melalui observasi yang dipengaruhi oleh orang lain/ lingkungan sekitar. contohnya ketika anak melihat perilaku dari orang tuanya kemudian meniru perilaku terserah karena sejatinya anak bukanlah pendengar yang baik melainkan peniru yang baik. Peniruan dalam hal ini mengarah ke hal yang positif sebagai salah satu bentuk pembelajaran dalam totalitas kehidupan anak baik di rumah, sekolah, persekutuan di gereja dan sosialisasi dalam masyarakat. Pendidikan sekolah formal hanya dilaksanakan secara instruksional Dalam hal ini orang tua perlu selektif dalam memilih sekolah untuk anaknya. Orang Tua yang 
tidak menanamkan kedisiplinan terhadap anaknya akan menghadapi akibat yang dapat menyakitkan di kemudian hari baik pada diri orang tua maupun pada diri anak itu sendiri.

\section{Tujuan dan Manfaat}

Tujuan dan manfaat dari pengembangan ini ialah untuk mencari tahu peran orang tua dalam mendidik dan membentuk iman dan karakter anak.

\section{Pembahasan}

\section{A. Iman}

Pendidikan iman sejatinya bukan satu-satunya diperoleh melalui pendekatan sekolah formal. Iman lebih dominan dipelajari justru melalui budaya; dan secara konkrit lebih banyak melalui keteladanan dan interelasi individual. Kepercayaan atau iman lebih dipengaruhi melalui pembentukan kultur. Pendidikan sekolah formal bukan jaminan bagi pendidikan iman. Tentu ada saja hal baik yang diperoleh melalui pendidikan sekolah formal, khususnya hal kognitif; namun ada juga sisi transformasi karakter individu, yang lazim terjadi justru pada kepala sekolah dan guru seringkali terjebak memposisikan diri sebagai pengamat atau kritikus belaka. Padahal, mereka sesungguhnya adalah aktor perubahan. Artinya, pemosisian diri secara struktural cenderung mempertahankan kemapanan atau antiperubahan. ${ }^{1}$

Pembelajaran mandiri dapat dinilai sebagai pendekatan yang utuh, karena memberi peluang yang sangat besar bagi anak-anak sebagai sumber untuk belajar dan mengalami sendiri berbagai dinamika di lingkungannya. Segala realita yang diamati anak menjadi media dialektika bebas yang membentuk karakter dalam dirinya. ${ }^{2}$

Pada umumnya, guru hanya berperan sebagai pawang yang mendidik anak dengan materi ajar. Anak hanya belajar untuk mendapatkan ranking demi nama baik orang tua. Kepentingan anak menjadi semakin terabaikan karena anak hanya belajar untuk

\footnotetext{
${ }^{1}$ Rannu Sanderan, EXEMPLARY, menemukenali kunci pendidikan kristen bagi anak dalam keluarga dan pembelajaran agama di sekolah https://osf.io/bmtrk/

${ }^{2}$ https://www.jurnalbia.com/index.php/bia/article/view/213
} 
menyenangkan orang tua dan guru dengan mendapatkan nilai baik, juga untuk memenuhi kebutuhan industri.

\section{B. Karakter}

Karakter dan kepribadian yang dibentuk melalui katalisasi minat dan antusiasme merupakan modal yang besar untuk memperoleh sesuatu. Dengan minat seseorang akan memperhatikan sesuatu objek belajar dengan mencurahkan sepenuh-penuhnya kesadaran, tenaga, waktu, peluang dan fasilitas yang dimilikinya demi mendalami objek belajarnya.

Dalam dunia pendidikan sendiri, penanaman nilai dan pembentukan karakter tidak memberi tempat pada realita intuisi. Tidak menuntun anak pada kesadaran intuitif dan peniadaan kesadaran diri. padahal menurut Paulo Freire otentisitas seorang anak justru dibangun melalui kesadaran kritis seseorang. ${ }^{3}$ Segala realita yang diamati anak menjadi media dialektika bebas yang membentuk karakter dalam dirinya.

Seorang anak dapat memiliki nilai hidup dan karakter justru dengan bantuan kebiasaan. Keteladanan dapat memupuk pertumbuhan kepribadian dan karakter jika seorang anak telah memiliki modal dalam bentuk minat. Minat muncul dari dalam pikiran dan hati seseorang untuk mendorongnya melakukan sesuatu. ${ }^{4}$

Orang tua memiliki peranan penting dalam pembentukan iman anak sebab mereka adalah generasi penerus baik dalam keluarga, gereja maupun bangsa. Itu sebabnya pembentukan iman anak tidak bisa diabaikan, anak-anak harus segera diperhatikan karena mereka akan bertumbuh menopang dan menjadi manusia masa depan Gereja. Orang tua harus melaksanakan perannya dengan benar agar anak-anak di dalam keluarga dan di tengah jemaat bertumbuh dalam imannya mendapatkan kepastian keselamatan dan memiliki pegangan yang kuat menjalani kehidupan di masa depan. ${ }^{5}$

Anak-anak akan tumbuh menjadi pribadi yang berkarakter apabila tumbuh pada lingkungan yang berkarakter. Untuk membentuk karakter anak ada tiga kebutuhan dasar yang harus dipenuhi yaitu:

\footnotetext{
${ }^{3}$ Rannu Sanderan, INTUISI: Pendalaman gagasan Hans-George Gadamer tentang intuisi sebagai supralogika https://ojs-jireh.org/index.php/jireh/article/view/39

${ }^{4}$ Rannu Sanderan, Heuristika dalam pendidikan karakter manusia Toraja Tradisional https://www.jurnalbia.com/index.php/bia/article/view/213 5https://www.researchgate.net/publication/347231922 Peran Orang Tua dalam Pembentukan Ima n_Anak_berdasarkan_2_Timotius_314-17 dan_Aplikasinya_di_GPdl_Elim_Aromarea___Serui__Pap ua
} 
a. Maternal bonding ( kelekatan psikologis dengan ibunya) merupakan dasar penting dalam pembentukan karakter anak karena aspek ini berperan dalam pembentukan dasar kepercayaan pada orang lain. Kelekatan ini membuat anak merasa diperhatikan dan menumbuhkan rasa aman dan rasa percaya.

b. Rasa aman, yaitu kebutuhan anak akan lingkungan yang stabil dan aman.

c. Kebutuhan akan stimulasi fisik dan mental juga merupakan aspek penting dalam pembentukan karakter anak. Hal ini membutuhkan perhatian yang besar dari orang tua dan reaksi timbal balik antara ibu dan anaknya.

Bilamana ketiga kebutuhan dasar anak terpenuhi, maka selanjutnya diperlukan adanya pola asuh yang dapat memaksimalkan pembentukan karakter anak. Keberhasilan keluarga dalam menanamkan nilai-nilai karakter pada anak sangat tergantung pada jenis pola asuh yang diterapkan orang tua pada anaknya.

\section{Peran Orang Tua}

Di dalam keluarga anak didik mulai mengenal hidupnya. Hal ini harus disadari dan dimengerti oleh setiap keluarga bahwa anak dilahirkan di dalam lingkungan kelurahan yang tumbuh dan berkembang sampai anak melepaskan diri dari ikatan keluarga. Suasana di dalam keluarga merupakan suasana yang diliputi rasa cinta, suasana yang aman, dan tentram. Melalui pendidikan keluarga kebutuhan emosional atau kebutuhan akan rasa kasih sayang dapat dipenuhi atau berkembang dengan baik hal ini karena adanya hubungan darah antara pendidik dan anak didik. Kehidupan emosional ini merupakan salah satu faktor yang terpenting di dalam membentuk pribadi seseorang.

Dalam keluarga merupakan tempat penamaan umat dasar-dasar moral bagi anak yang biasanya tercermin dalam sikap dan perilaku orang tua sebagai teladan yang dapat dicontoh anak. Dalam kehidupan keluarga juga sangat penting dalam peletakan dasar-dasar pendidikan sosial anak sabab pada dasarnya keluarga merupakan lembaga sosial yang resmi.

Keluarga sebagai lembaga pendidikan pertama dan utama, karena sangat menentukan dalam menanamkan dasar-dasar moral yang tak kalah pentingnya adalah berperan besar dalam proses internalisasi dan transformasi nilai-nilai keagamaan ke dalam pribadi anak. ${ }^{6}$ 
Kekeliruan orang tua dalam mendidik anaknya, hal tersebut akan mempengaruhi perkembangan kecerdasan emosi anak sehingga akan berakibat pada pembentukan karakter buruk pada anak. Bentuk perilaku orang tua seperti ini, yaitu:

1. Kurang menunjukkan ekspresi kasih sayang baik secara verbal maupun fisik.

2. Kurang meluangkan waktu yang cukup untuk anaknya.

3. Bersikap kasar secara verbal, misalnya menyindir,.mengecilkan anak, dan berkata-kata kasar.

4. Bersikap kasar secara fisik, misalnya memukul, mencubit, dan memberikan hukuman badan lainnya.

5. Terlalu memaksa anak untuk menguasai kemampuan kognitif secara dini.

6. Tidak menanamkan "good character" kepada anak.

Dampak atas kesalahan dalam menerapkan pola asuh akan menghasilkan anak-anak yang mempunyai kepribadian bermasalah atau mempunyai kecerdasan emosi rendah. Bentuk perilaku anak yang dapat muncul, yaitu:

1. Anak menjadi acuh tak acuh, tidak butuh orang lain,dan tidak dapat menerima persahabatan karena sejak kecil mengalami kemarahan, rasa tidak percaya, dan gangguan emosi negatif lainnya.

2. Aspek pembentukan emosi anak menjadi tidak responsif, dimana anak yang ditolak akan tidak mampu memberikan cinta kepada orang lain.

3. Berperilaku agresif, anak dengan mudah selalu terdorong untuk menyakiti temannya, baik secara verbal maupun fisik.

4. Anak menjadi minder, merasa diri tidak berharga dan tidak berguna.

5. Selalu berpandangan negatif pada lingkungan sekitarnya, seperti rasa tidak aman, khawatir, curiga dengan orang lain, dan merasa orang lain sedang mengkritiknya.

6. Ketidakstabilan emosional, yaitu tidak toleran atau tidak tahan terhadap stress, mudah tersinggung, mudah marah. ${ }^{7}$

\section{Kesimpulan dan Saran}

\section{A. Kesimpulan}


Peran orang tua dalam pembentukan iman dan karakter anak sangatlah penting karena anak adalah generasi penerus. Akan tetapi dalam membina anak bertumbuh dalam iman tidak mudah karena pada tingkat ini anak memiliki banyak tantangan sehingga anak perlu diarahkan ke arah yang positif. Lingkungan keluarga merupakan pendidikan pertama dan utama karena dalam keluarga akan mendapatkan pendidikan dan bimbingan pertama, demikian juga dalam di dalam keluarga anak banyak menerima pendidikan karena sebagian besar kehidupannya dihabiskan dalam keluarga. Peran dan tanggung jawab bapak dan ibu, dalam hal ini keluarga sangat menentukan dalam pembentukan karakter anak, karena bapak dan ibu pendidik utama bagi anak-anaknya.

\section{B. Saran}

Dalam membentuk iman dan karakter anak orang tua perlu berhati-hati karena banyaknya tantangan dari luar yang akan bisa mempengaruhi anak. Orang tua juga harus selalu senantiasa hati-hati dalam pemilihan sekolah untuk anak. 